Jurnal Abdiraja

ISSN : 2621-9379 (Online)

Volume 3, Nomor 2, September 2020

\title{
UPAYA PENINGKATAN SISTEM OPERASIONAL PENYEDIAAN PERMAKANAN DI KECAMATAN KALIRUNGKUT SURABAYA
}

\author{
Deograsias Yoseph Yustinianus Ferdinand ${ }^{1}$, Yehezkiel Sony Satriawan ${ }^{2\}}$ \\ ${ }^{(1)}$ Fakultas Ekonomi, ${ }^{(2)}$ Fakultas Teknik \\ ${ }^{1,2)}$ Universitas Katolik Darma Cendika \\ Email : dyoseph279@gmail.com ${ }^{1)}$ Yehezkielsony99@gmail.com ${ }^{2)}$
}

\begin{abstract}
ABSTRAK
Kebutuhan yang menopang kehidupan manusia terdiri dari 3 hal yaitu adanya sandang, papan, dan pangan. Hal tersebut menjadi bagian kebutuhan utama yang harus dipenuhi oleh setiap manusia. Dalam pemenuhan kebutuhan utama tersebut manusia memerlukan sebuah usaha, salah satunya dengan cara bekerja sehingga mendapatkan pemenuhan 3 kebutuhan utama tersebut. Namun apabila melihat dari kenyataan yang terjadi tidak setiap manusia mampu memenuhi kebutuhan utama tersebut karena berbagai macam faktor, salah satunya terkait usia. Dinas Sosial Surabaya menilai bahwa pada usia lanjut, seseorang tidak lagi berada dalam usia bekerja sehingga pemenuhan kebutuhan utama tentu tidak akan dapat terpenuhi secara maksimal, salah satunya terkait masalah pemenuhan pangan. Melalui hal ini Dinas sosial Surabaya memiliki kebijakan berupa perbantuan permakanan yang merupakan salah satu yang terpenting dalam 3 kebutuhan utama manusia. Program pemenuhan kebutuhan pangan ini disebut dengan program permakanan. Program permakanan ini diadakan untuk membantu pemenuhan kebutuhan terkait asupan pangan terutama bagi masyarakat lanjut usia. Program ini dilaksanakan dengan bantuan para pelaksana di setiap Kecamatan di Surabaya. Program permakanan lanjut usia yang penulis laksanakan berada di Kecamatan Kali Rungkut dan selama ini telah berjalan selama 5 tahun sejak tahun 2014. Ada 3 hal yang perlu dibenahi dati program ini adalah: kelancaran proses operasional yang akan memberikan manfaat, pembangunan infrastruktur untuk memperlancar pengiriman kotak makan, dan penambahan gizi yang berguna bagi penetima manfaat
\end{abstract}

Kata Kunci : Dinas Sosial dan Permakanan

\section{PENDAHULUAN}

"Fakir miskin dan anak-anak terlantar dipelihara oleh negara". Itulah bunyi pasal 34 ayat 1 Undang-Undang Dasar 1945. Pemerintah Kota (Pemkot) Surabaya mengaplikasikan pasal tersebut, salah satunya melalui program pemberian makanan (permakanan) yang sudah dimulai sejak 2012.Ada tiga sasaran utama program permakanan di Surabaya. Yakni, lansia terlantar, anak yatim dan penyandang disabilitas. Oleh karenanya, perangkat kecamatan maupun kelurahan punya kewajiban mendata calon penerima permakanan di wilayah masing-masing.Selanjutnya, data itu akan diverifikasi dinas sosial. Penerima 
Jurnal Abdiraja

ISSN : 2621-9379 (Online)

Volume 3, Nomor 2, September 2020

program tersebut mendapatkan makanan gratis

yang dikirim ke rumah setiap harinya. Untuk

menjamin pemenuhan gizi penerima program permakanan, dinas social yang bertanggung jawab atas program permakanan ini berkoordinasi

dengan ahli gizi Dinas Kesehatan Kota Surabaya. Menu makanan juga berubah-ubah secara periodik agar penerima program tidak bosan.

Berdasar data Dinas Sosial Kota Surabaya, penerima program permakanan tahun 2019 mencapai 35.414 orang. Rinciannya, lansia dan pra-lansia 20.000 orang, anak yatim, piatu dan yatim piatu sebanyak 6.000 anak, serta penyandang disabilitas sebanyak 9.414 orang. Sedangkan Keluarga Penerima Manfaat(KPM) khususnya lansia di Kelurahan Kalirungkut Surabaya berjumlah 89 orang.

\section{Adanya program permakanan menjadi} salah satu trobosan pemerintah kota Surabaya untuk menangani masalah kesejahteraan masyarakat. Salah satunya adalah permakanan di bidang lanjut usia (lansia) yang sedang Penulis observasi. lansia yang telah Penulis temui di daerah Kecamatan kalirungkut, dimana kita melihat kondisi lansia tersebut. Permasalahan yang
Penulis anggap sangat penting untuk diselesaikan dengan segera adalah permasalahan mengenai wadah tempat pengirim melakukan pengiriman karena berefek pada keadaan makanan yang akan dikirim dan diberikan ke penerima permakanan.

\section{METODE PELAKSANAAN}

\section{Kerangka Pemecahan Masalah}

Program permakanan kota Surabaya khususnya kecamatan kali rungkut telah berjalan dengan baik. Namun, setelah peneliti melakukan observasi selama 3 bulan, peneliti juga melihat beberapa hal yang perlu ditingkatkan kembali. Ini dikarenakan Dinas Sosial menyerahkan tugas pembagian makannya setiap hari kepada Panitia Pelaksana di setiap Kelurahan

Dari hsil observasi peneliti, ada beberapa permasalahan yang perlu diperhatikan yaitu, fasilitas yang digunakan untuk pengiriman kotak makanan kurang mendukung serta kurang menjamin kualitas makanan yang akan diberikan kepada penerima. Kondisi tersebut disebabkan oleh tas motor yang digunakan mengirim makanan belum mendapatkan pembaharuan.Sehingga untuk menyelesaikan 
gandeng, hal ini dikarenakan menurut

masalah yang perlu diselesaikan dengan baik tersebut, peneliti memberikan bantuan dalam hal pembaharuan tas motor yang digunakan untuk mengirim kotak makanan yang dissesuaikan dengan kondisi Motor Pengirim makanan kepada penerima manfaat, tidak hanya itu untuk menambah gizi yang dibutuhkan oleh penerima manfaat, peneliti juga berinisiatif untuk memberikan tambahan gizi, serta rekomendasi Standard Operasional Prosedur (SOP) agar program permakanan kota Surabaya yang telah berjalan dengan baik ini, terus mengalami peningkatan dan semakin baik dalam pelaksanaannya.

\section{Realisasi Pemecahan Masalah}

Realisasi program kerja yang telah peneliti rencanakan rencanakan ada 3 kegiatan, yaitu mendampingi Panitia Pelaksana ketika membagikan kotak makanan kepada 89 Penerima Manfaat, kegiatan memberikan bantuan tas motor beserta tambahan gizi berupa beberapa dus susu serta pembuatan rekomendasi SOP. Pemberian tas gandeng dan tambahan gizi Penulis berikan secara langsung kepada penyedia permakanan yang juga bertugas sebagai pengirim sejumlah 3 buah tas pernyataan pengirim setiap harinya pengirim menggunakan 3 (tiga) sepeda motor untuk mengirim makan. Kemudian, kegiatan penyusunan rekomendasi SOP Penulis lakukan dengan melihat SOP yang telah dan menganalisa apa saja perlu ditingkatkan.

\section{Khalayak Sasaran}

Sasaran dari kegiatan yang Penulis lakukan adalah seluruh pihak yang terkait dalam program permakanan khusunya daerah kali rungkut, mulai dari dinas sosial, pelaksana, penyedia, pengirim, hingga penerima.

\section{HASIL DAN PEMBAHASAN}

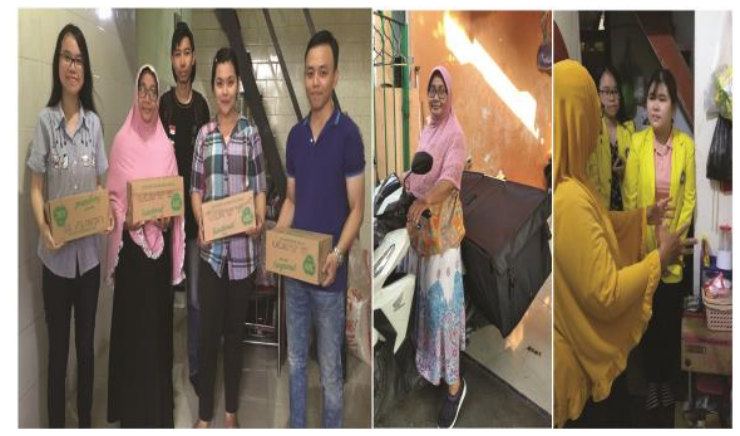

Gambar 1.Pembagian susu dan Tas Motor

\section{Tahap Kegiatan}

Tahapan kegiatan yang di lakukan di kecamatan Kali Rungkut adalah:

1. Memberikan bantuan dalam hal 
pembaharuan tas motor yang digunakan untuk mengirim kotak makanan, serta memberikan tambahan gizi,

2. Rekomendasi Standard Operasional Procedure (SOP) untuk program permakanan di kota Surabaya.

3. Sebelum menyimpulkan untuk fokus melakukan hal diatas, Penulis telah mendampingi Pelaksanaan Pembagian kotak makanan dari mulai Pelaksana sampai kotak makanan diterima secara langsung oleh Penerima Manfaat

\section{Perubahan yang Terjadi}

Perubahan yang terjadi setelah Penulis mengadakan bantuan pemberian tas motor, tambahan gizi, dan rekomendasi SOP adalah masyarakat khususnya penerima bantuan permakanan dari Dinas Sosial Pemerintah Kota Surabaya merasa senang dengan adanya penambahan gizi. Sedangkan bagi penyedia permakanan khususnya wilayah kecamatan Kali Rungkut merasa bersyukur karena menerima bantuan pembaharuan tas motor yang digunakan untuk mengirimkan kotak makanan, yang sebelumnya telah rusak dan tidak layak pakai lagi.

\section{Rencana Keberlanjutan Program}

Rencana kelompok Penulis selanjutnya adalah Penulis memberikan rekomendasi kepada Dinas Sosial, agar program ini dapat diterapkan pada setiap kecamatan di kota Surabaya yang menerima program bantuan permakanan.

\section{PENUTUP}

\section{Kesimpulan}

Setelah melaksanakan kegiatan Pengabdian Masyarakat di Kelurahan Kali Rungkut, Penulis mendapatkan banyak pengalaman. Dari apa yang Penulis dapatkan dan Penulis amati, Penulis menyimpulkan bahwa program bantuan permakanan merupakan salah satu program yang sangat bermanfaat bagi masyarakat terutama lansia di kota Surabaya. Pada program permakanan ada seorang penyedia permakanan yang memiliki tugas untuk menyiapkan makanan untuk disalurkan ke penerima permakanan.

Tugas seorang penyedia permakanan tidak hanya dilakukan sebagai suatu pekerjaan namun juga sebagai pengabdian kepada masyarakat yang membutuhkan 
Jurnal Abdiraja

ISSN : 2621-9379 (Online)

Volume 3, Nomor 2, September 2020

gizi yang cukup dalam segi makanan.

Penyedia yang sekaligus sebagai pengirim tidak memandang upah yang didapat.

Sehingga perlu adanya rasa kepedulian yang tinggi dalam pekerjaannya.

Pemberian permakanan kepada lansia memang membutuhkan kesabaran dalam menyiapkan makanan dan menghadapi penerima makanan yang telah lansia. Maka dari itu perlu adanya semangat yang tinggi dalam menjalankan program permakanan lansia agar program permakanan dapat berjalan dengan baik.

\section{Saran}

Penulis mengharapkan program kerja Penulis dapat diadobsi oleh Dinas Sosial agar program yang telah Penulis lakukan dapat diterapkan di seluruh kecamatan yang melaksanakan program bantuan permakanan agar program permakanan yang telah baik adanya menjadi lebih baik lagi.

\section{DAFTAR PUSTAKA}

Erwan dan Dyah. 2012, Implementasi Kebijakan

Publik: Konsep dan Aplikasinya. Yogyakarta:

Penerbit Gava Media
Kurniawan, Agung. 2015. Transformasi Pelayanan Publik. Yogyakarta: Pembaruan

UUD RI, No.13 Tahun 1998. Tentang Kesejahteraan Lanjut Usia

Undang Undang Dasar 1945 